\title{
The Factors That Affect To Attract Deposits in Palestinian Islamic Banks
}

\author{
Amer Saadi Jaber \\ Islamic finance \\ Jinan University - Lebanon \\ Tel: 97-059-937-4274Ｅ-mail: amer.jaber2010@hotmail.com \\ Mohammed Shuaib Manasrah \\ Islamic finance \\ Jinan University - Lebanon \\ Tel: 97-059-911-2555Ｅ-mail: manasrah503@gmail.com
}

\author{
Received: Feb.2, $2017 \quad$ Accepted: April 27, $2017 \quad$ Published: June 1, 2017 \\ doi:10.5296/ajfa.v9i1.11020 URL: http://dx.doi.org/10.5296/ajfa.v9i1.11020
}

\begin{abstract}
This study aims to identify the factors that affect to attract deposits in Palestinian Islamic banks. The researcher used the descriptive approach to reach the results and recommendations of the study. The study society is a branches manager of Islamic banks operating in Palestine. The sample was the Sam of study society; because the small size of study society. It found that there is a relation between the geographical location of the branches of Islamic banks, advertising campaigns and promotion, diversification, development of services, experience of bank staff, and attracting deposits in Islamic banks in Palestine.

The study recommended that the Islamic banks in Palestine continuously provide savings campaigns to increase deposits, and must choose locations based on the recommendations of branch managers and the involvement of marketing departments. In addition, they should increase investment in human resources in terms of training, qualification. And work to provide them with the necessary skills to attract customers.
\end{abstract}

Keywords: Islamic banks, attracting deposits, Palestine, Palestinian Monetary Authority, branch managers. 


\section{Introduction}

Bank deposits are one of the most important elements on which banks are based in general, whether Islamic or commercial. It is a service to the client on the one hand, is the preservation or investment, and the supplier of the bank is an obligation on the other hand is the ability to grant facilities to other customers. The deposit is an agreement between the client and the bank Under which the customer to deposit a sum of money with the bank for the purpose of conservation or investment and the bank undertakes to refund the money to the client at a certain date upon request, according to terms agreed upon in advance.

Islamic banks are competing to increase their deposits due to the basic rule of the Islamic banks based on participation in profit or loss. Islamic banks rely on speculation in the implementation of financial transactions related to deposits. It should be noted that the laws and instructions issued by the Central Bank In the country has a significant impact on the size of deposits with any bank, where the proportion of deposits to facilities by the Central Bank and be obliged to grant funds or attract deposits.

The emergence of the Islamic banks in Palestine began after the arrival of the Palestinian Authority in 1996 and the signing of the Paris Economic Agreement in 1994. Article 4 of the Paris Economic Protocol concluded between the Palestinians and the Israeli side establishes a monetary authority that supervises and inspection the work of the banking sector, as it will become the financial agent of the Palestinian Authority in the control of Financial Policy, and works in Palestine until the end of 2016 three Islamic banks are the Arab Islamic Bank and the Palestinian Islamic Bank and Safa Bank.

\section{Methodology}

The study was based on the descriptive analytical approach. The Secondary data were obtained from relevant books and financial reports. In addition, the primary data were collected from the study population and were analyzed statistically to obtain the results of the study. The questionnaire was a primary data collection tool that is aimed to identifying the most important factors for attracting deposits in Palestinian Islamic banks.

Deposits play an important role in the banking process. As they are considered the most important pillars of banking activity, and as the demand of customers have become increasing on Islamic banking, this study will try to answer the main study question, which is the problem of study:

What are the factors that affect the attraction of deposits in Palestinian Islamic banks?

There are a several sub-questions that the study will try to answer:

What is the impact of the geographic location of branches of banks in attracting deposits in Palestinian Islamic banks?

What is the impact of advertising and promotional campaigns in attracting deposits in Palestinian Islamic banks? 
What is the impact of diversification and development of services provided in attracting deposits in Palestinian Islamic banks?

What is the impact of the experience of the customer service staff in attracting deposits in the Palestinian Islamic banks?

This study aims to identify the geographical location of bank branches, advertising and promotional campaigns, diversify and develop the services provided and the experience of the customer service staff in attracting deposits in the Palestinian Islamic banks.

The importance of this study stems from the role played by Islamic banks as an alternative to commercial or conventional banks. The banking sector in general is considered one of the most important economic poles of the country. This study acquires scientific importance as a recent study within the limits of the researcher's knowledge. The Islamic Bank has to make and provide them in order to attract and increase deposits. Its practical importance is due to the study's findings to the decision-makers of Islamic banks in Palestine to find new ways to attract deposits and increase savings.

\section{Hypotheses of the study}

The following hypotheses were formulated in an attempt to answer the questions posed by the study:

There is a statistical relationship between attracting deposits and the geographical location of branches of Palestinian Islamic banks.

There is a statistical relationship between attracting deposits and advertising and campaigns promoted by Islamic banks.

There is a statistical relationship between attracting deposits and diversifying and developing the services of Palestinian Islamic banks.

There is a statistical relationship between attracting deposits and the experience of customer service staff in Palestinian Islamic banks.

\section{Society and Study Sample}

The study Society consist the branch managers of the Islamic banks operating in Palestine. And the number of branches of the Islamic banks (45) distributed throughout Palestine. The survey population will be completely surveyed so that the sample is the same as the study population due to the small size of the study society.

\section{Statistical treatments}

After the data was collected and processed statistically using the statistical program (SPSS) using the following statistical treatments:

5.1 Calculations, percentages, and repetitions to calculate the relative weight of the subjects and areas of the study instrument

5.2 Examining the stability of the questionnaire using the formula Alpha Kronbach. 


\section{Literature Review}

\subsection{Previous studies}

6.1.1 Almejyesh \& Rajha, (2014), a study entitled "Behavioral Determinants and Their Impact on Customer Savings Deposits in Islamic Banks in Saudi Arabia".

This study aimed to test the behavioral determinants that affect customers, savings deposits in Islamic banks in Saudi Arabia of a sample of three Islamic banks are: AlRajhi Bank, Bank Al-Bilad, and Al-Inma Bank. The researchers used the descriptive approach to reach the results of the study. The study reached several results. The most important of which is geographical spread, distribution of profits and religious beliefs are the most factors that attract customers to choose the Islamic Bank. The study recommended the need to increase the awareness of customers in Islamic banking, which will lead to maximizing deposits with Islamic banks.

6.1.2 Cevik and Charap, (2011), a study entitled "the behavior of return on deposits of Islamic banks and conventional banks in Malaysia and Turkey"

This study aimed to test the behavior of interest rates on bank deposits at conventional banks and the rate of return on investment accounts involved in the profit and loss among Islamic banks. The analysis of the financial ratios was used to reach results that could be published and disseminated. The sample included traditional and Islamic banks in Turkey and Malaysia during the period 1997-2010. The study focused on explaining the factors influencing deposits in both types of banks. The study concluded that interest rates in conventional banks integrated with Investment accounts in Islamic banks in the long term.

6.1.3. Mohammed,(2010), a study entitled "The strategy of attracting and maintaining deposits in the banking sector, applying to the tadamon Islamic Bank in Sudan".

The study aimed to finding out the practical way to develop an appropriate strategy for attracting deposits, and to know the impact of applying the strategy of attracting deposits and preventing their leakage in the tadamon Islamic Bank. The most important results of the study are the existence of the marketing strategy in the bank leading to attract new customers and thus increase bank deposits. The study recommended that we need to seek to attract funds outside the banking system and its necessary to increase the training and rehabilitation of employees in Islamic banks.

6.1.4. Abu Samra, (2007), a study entitled "developing the policy of bank deposits under the liability management theory" An Empirical study on commercial banks operating in Palestine.

The study aimed to identify the factors leading to the decrease in deposits in commercial banks in Palestine. The researcher used the analytical descriptive method. The study society is the managers of commercial bank branches in Palestine. The study concluded that there is a relationship between the size of deposits and the level of economic activity. The study recommended that we need to develop policy of branch managers to attract deposits. 


\subsection{The Situation of This Study from Previous Ones}

This study differs from other studies in the following points:

6.2.1 The study examines the Factors that Affect to Attract Deposits in Palestinian Islamic Banks from four dimensions: the geographic location, the advertising and promotional campaigns, the diversification and development of services, and the experience of the customer service staff.

6.2.2 Previous studies have focused on the factors influencing customer attraction from the point of view of customers, but this study is a modern and unique according to the researcher knowledge, and it focused on the factors affecting the attractiveness of clients from the point of view of branch managers.

\section{The Characteristics of the Study Sample}

The number of forms that have been distributed 45 forms, while returned 40 forms; this makes a response to high and forms up to $88 \%$ of the number of forms distributed. And all the forms are valid for analysis.

\section{Description of Personal Respondents}

Table (1) shows a description of the personal factors of the sample of branch managers of Islamic banks in Palestine as follows:

1. Age: $50 \%$ of the sample More than 40 years, $37.5 \%$ between $30-40$ years, $12.5 \%$ Less than 30 years.

This means that the age group above 40 years is the majority in the study sample. This is proportional to the practical experience. The more practical experience, the more able to manage the banking operations.

It should be noted that the instructions of the Palestinian Monetary Authority in the appointment of branch managers require that the candidate for the branch management have at least 8 years of practical experience.

2. Qualifications: The study showed that $82.5 \%$ of the study sample held bachelor degrees, $12.5 \% 7.41 \%$ of the sample held masters, $5 \%$ of the sample are diploma holders, $0 \%$ of the sample held P.H.D degree.

This means that the bachelor degree is the majority of the sample of the study, and this is consistent with the requirements of the Palestinian Monetary Authority to appoint branch managers.

3. Years of experience: The study showed that $62 \%$ of the samples have experience between 10 - 15 years, $27.5 \%$ have experience more than 15 years, and $10 \%$ of the samples have experience less than 10 years. 


\section{Macrothink}

Asian Journal of Finance \& Accounting

ISSN 1946-052X

2017, Vol. 9, No. 1

4. Specialization: $42.5 \%$ of the sample specialized in Business administration, $25 \%$ specialized in finance, $25 \%$ specialized in accounting, and $7.5 \%$ specialized in Islamic finance.

An analysis of the specialization variable shows that there is rarity in Islamic finance specialization, or that Islamic banks do not assign Islamic finance disciplines to supervisory positions.

Table 1. Frequencies and percentages for the personal variables of respondents

\begin{tabular}{|l|l|c|c|}
\hline \multicolumn{2}{|l}{ Factor } & Freq & $\mathbf{\%}$ \\
\hline \multirow{4}{*}{ Age } & Less than 30 years & 5 & 12.5 \\
\cline { 2 - 4 } & From 30-40 years & 15 & 37.5 \\
\cline { 2 - 4 } & More than 40 years & 20 & 50 \\
\cline { 2 - 4 } & Total & $\mathbf{4 0}$ & $\mathbf{1 0 0}$ \\
\hline \multirow{5}{*}{ Qualifications } & Diploma & 2 & 5 \\
\cline { 2 - 4 } & Bachelor & 33 & 82.5 \\
\cline { 2 - 4 } & Master & 5 & 12.5 \\
\cline { 2 - 4 } & PhD & 0 & 0 \\
\cline { 2 - 4 } & Total & $\mathbf{4 0}$ & $\mathbf{1 0 0}$ \\
\hline \multirow{5}{*}{ Specialization } & less than 10 years & 4 & 10 \\
\cline { 2 - 4 } & From 10-15 years & 25 & 62.5 \\
\cline { 2 - 4 } & more than 15 years & 11 & 27.5 \\
\cline { 2 - 4 } & Total & $\mathbf{4 0}$ & $\mathbf{1 0 0}$ \\
\hline & Accounting & 10 & 25 \\
\cline { 2 - 4 } & Finance & 10 & 25 \\
\cline { 2 - 4 } & Business & & \\
\hline & Administration & 17 & 42.5 \\
\cline { 2 - 4 } & Islamic finance & 3 & 7.5 \\
\cline { 2 - 4 } & Total & $\mathbf{4 0}$ & $\mathbf{1 0 0}$ \\
\hline
\end{tabular}

\section{Stability of the Tool}

Stability of the tool was tested by Cronbach Alpha Coefficient test; Table (2) shows the following:

8.1 The alpha value for the items of the geographic location to attracting deposits was 0.72 .

8.2 The alpha value for the items of the advertising and campaignsto attracting deposits was 0.76 .

8.3 The alpha value for the items of the diversifying and developing to attracting deposits was .85 .

8.4 The alpha value for the items of the experience of customer service staff to attracting deposits was 0.82 . 
Table 2. Alpha Cronbach values

\begin{tabular}{|l|c|c|c|c|}
\hline variable & Paragraph & $\begin{array}{c}\text { Number of } \\
\text { paragraphs }\end{array}$ & $\begin{array}{c}\text { Number of } \\
\text { answers }\end{array}$ & $\begin{array}{c}\text { Cronbach } \\
\text { Alfa }\end{array}$ \\
\hline geographical location & $1-7$ & 7 & 40 & 0.72 \\
\hline advertising and campaigns & $8-13$ & 6 & 40 & 0.76 \\
\hline diversifying and developing & $14-19$ & 6 & 40 & 0.85 \\
\hline $\begin{array}{l}\text { experience of customer } \\
\text { service staff }\end{array}$ & $20-24$ & 5 & 40 & 0.82 \\
\hline all variable & $\mathbf{1}-\mathbf{2 4}$ & $\mathbf{2 4}$ & $\mathbf{4 0}$ & $\mathbf{0 . 8 3}$ \\
\hline
\end{tabular}

All values in table 2 were $>0.60$ that means a stability of the tools (scatter 19), it thus reflects the stability of the questionnaire paragraphs, enabling them to measure and examine the questions that the study has gone through.

The scale was designed based on a five-dimensional Likert scale. The paragraphs were built in a positive direction and weights were given to the paragraphs as follows: Strongly agree: five degrees, agree: four degrees, neutral: three degrees, Disagree: two degrees, strongly disagree: one degree. The default is medium (3) which can be found by calculating the average of the previous options $(5+4+3+2+1) \div 5$.

So if the average variable (3) or above that means that the study sample tend to accept the presence of variable importance in attracting deposit, the higher of average increased the degree of acceptance by the respondents. If the average lower than average variable default (3) it means that the study sample tend not to accept the presence of the impact of variable selection, the lower the average figure (3) more no acceptance by members of the study sample.

Table3. Estimating the level of factors affecting attracting deposits in Islamic banks in Palestine

\begin{tabular}{|c|c|c|}
\hline Range & \% & Estimate the level of the role \\
\hline less than 3.44 & $\%$ 68.8less than & very low \\
\hline $3.82-3.44$ & $\% 76.4-68.8 \%$ & Low \\
\hline $4.21-3.83$ & $\% 84.2-76.5$ & moderate \\
\hline $4.60-4.22$ & $\% 92.0-84.3$ & high \\
\hline
\end{tabular}

\section{Hypotheses}

\section{1 test of First hypothesis}

There is a statistical relationship between attracting deposits and the geographical location of branches of Palestinian Islamic banks.

The table (4) shows that all grouped items have a mean of 4.37, is the larger of about 1.37 average defaults (3). This means that this hypothesis is accepted. And there is a statistical 
relationship between attracting deposits and the geographical location of branches of Palestinian Islamic banks.

Table (4) shows that the geographic location of branches of Islamic banks in Palestine plays a high role in attracting deposits. Paragraphs (1, 2, and 3) have a very high effect. The percentage of respondents' $(93.6,92.8,93.1)$ respectively, while in paragraphs $(4,5)$ have a high effect, the percentages of responses (90.4 and 89.6) respectively were moderate in paragraph (6) Per cent (81.6), and was low in paragraph (7) where the percentage of percentage of respondents' (71.2).

The overall degree of geographical location was high, with the overall percentage of responses in this area (89.2).

Table 4. Arithmetical averages, standard deviations and percentages of the geographical location of branches of Islamic banks

\begin{tabular}{|c|l|c|c|c|c|}
\hline No & \multicolumn{1}{|c|}{ Paragraph } & $\begin{array}{c}\text { arithmeti } \\
\text { c } \\
\text { means }\end{array}$ & $\begin{array}{c}\text { standard } \\
\text { deviations }\end{array}$ & \% & $\begin{array}{c}\text { relative } \\
\text { importanc } \\
\text { e }\end{array}$ \\
\hline 1 & $\begin{array}{l}\text { Your bank has obvious plan for selecting } \\
\text { branches based on estimates of deposit } \\
\text { concentration. }\end{array}$ & 4.68 & 0.69 & 93.6 & very high \\
\hline 2 & $\begin{array}{l}\text { Branches are selected sites based on the } \\
\text { size of business activity in the } \\
\text { surrounding area. }\end{array}$ & 4.64 & 0.49 & 92.8 & very high \\
\hline 3 & $\begin{array}{l}\text { Your bank takes Population density } \\
\text { when choosing branch locations. }\end{array}$ & 4.63 & 0.63 & 93.1 & very high \\
\hline 4 & $\begin{array}{l}\text { Your bank branches more in the city } \\
\text { than in the countryside. }\end{array}$ & 4.52 & 0.77 & 90.4 & high \\
\hline 5 & $\begin{array}{l}\text { Branches are selected sites based on the } \\
\text { reports of deposits in ATMs near the } \\
\text { target area for the opening of branches. }\end{array}$ & 4.48 & 0.87 & 89.6 & high \\
\hline 6 & $\begin{array}{l}\text { When selecting branch locations, your } \\
\text { bank will consider the absence of } \\
\text { branches of competing Islamic banks. }\end{array}$ & 4.08 & 1.19 & 81.6 & moderate \\
\hline 7 & $\begin{array}{l}\text { Your bank is based on a feasibility study } \\
\text { when selecting branch locations. }\end{array}$ & 3.56 & 1.16 & 71.2 & Low \\
\hline
\end{tabular}

In analyzing the above data, it is clear to us that the location of the branch has high impact on attracting deposits. This is because the Islamic banks in Palestine tend to choose their branch locations based on the concentration of deposits, selected sites based on the size of business activity in the surrounding area, and this is consistent with the study of Almejyesh \& Rajha (2014), which concluded that geographical spread plays an important role in attracting deposits. 


\subsection{Second Hypothesis}

There is a statistical relationship between attracting deposits and advertising and campaigns promoted by Islamic banks.

The table (5) shows that all grouped items have a mean of 4.4,is the larger of about 1.40 average default (3), which means that this hypothesis is accepted, and there is a statistical relationship between attracting deposits and the promotional campaigns offered by Islamic banks in Palestine.

Table (5) shows that the promotional campaigns offered by Islamic banks in Palestine plays a high role in attracting deposits. Paragraphs $(1,2,3$, and 4) have a high effect. The percentage of respondents' $(91.2,91.2,89.6$, and 89.6) respectively, while in paragraphs $(5,6)$ have a moderate effect, the percentages of responses (84and 83.2) respectively.

The overall degree of geographical location was high, with the overall percentage of responses in this area (88.1).

Table 5. Arithmetical averages, standard deviations and percentages of the promotional campaigns offered by Islamic banks in Palestine

\begin{tabular}{|c|l|c|c|c|c|}
\hline No & \multicolumn{1}{|c|}{ Paragraph } & $\begin{array}{c}\text { arithmetic } \\
\text { means }\end{array}$ & $\begin{array}{c}\text { standard } \\
\text { deviations }\end{array}$ & \% & $\begin{array}{c}\text { relative } \\
\text { importance }\end{array}$ \\
\hline 1 & $\begin{array}{l}\text { Your bank has a specialized } \\
\text { department in promotional and } \\
\text { promotional campaigns. }\end{array}$ & 4.56 & 0.51 & 91.2 & high \\
\hline 2 & $\begin{array}{l}\text { The Branch Manager has the authority } \\
\text { to offer gifts to customers without } \\
\text { reference to the General } \\
\text { Administration. }\end{array}$ & 4.56 & 0.71 & 91.2 & high \\
\hline 3 & $\begin{array}{l}\text { Existing and potential customers are } \\
\text { notified of campaigns by all Methods } \\
\text { of communication. }\end{array}$ & 4.48 & 0.51 & 89.6 & high \\
\hline 4 & $\begin{array}{l}\text { Your bank updates and renews } \\
\text { promotional and campaigns that result } \\
\text { in an increase in deposits. }\end{array}$ & 4.48 & 0.51 & 89.6 & high \\
\hline 5 & $\begin{array}{l}\text { Your bank is allocated savings } \\
\text { campaigns for specific segments of } \\
\text { the community. }\end{array}$ & 4.2 & 0.82 & 84 & moderate \\
\hline 6 & $\begin{array}{l}\text { Your bank is promoting the culture of } \\
\text { savings through advertising and } \\
\text { promotional campaigns. }\end{array}$ & 4.16 & 0.75 & 83.2 & moderate \\
\hline \multicolumn{2}{|l|lll}{ grouped items } & $\mathbf{4 . 4}$ & $\mathbf{0 . 2 7}$ & $\mathbf{8 8 . 1}$ & high \\
\hline
\end{tabular}

In analyzing the above data, we show that the promotional campaigns offered by Islamic banks in Palestine have high impact in attracting deposits. This is because the Islamic banks 
in Palestine specialized department in promotional and promotional campaigns and the Branch Manager has authority to offer gifts to customers without reference to the General Administration, and the bank updates, renews promotional, and campaigns that result in an increase in deposits.

\subsection{Third hypothesis}

There is a statistical relationship between attracting deposits and diversifying and developing the services of Palestinian Islamic banks.

The table (6) shows that all grouped items have a mean of 4.1, is the larger of about 1.10 average defaults (3), which means that this hypothesis is accepted, and there is a statistical relationship between attracting deposits and the diversifying and developing the services of Palestinian Islamic banks.

Table (6) shows that the diversifying and developing the services of Palestinian Islamic bank splay a moderate role in attracting deposits. Paragraphs (1 and2) have a high effect. The percentage of respondents' (88.8 and 85.6) respectively, while in paragraphs $(3,4$, and 5) have a moderate effect, the percentages of responses $(83.2,83.2$ and 82.4$)$ respectively.

The overall degree of diversifying and developing the services was moderate, with the overall percentage of responses in this area (83).

Table 6. Arithmetical averages, standard deviations and percentages of the diversifying and developing the services of Palestinian Islamic banks

\begin{tabular}{|c|c|c|c|c|c|}
\hline No & Paragraph & $\begin{array}{c}\text { arithmetic } \\
\text { means }\end{array}$ & $\begin{array}{c}\text { standard } \\
\text { deviations }\end{array}$ & $\%$ & $\begin{array}{c}\text { relative } \\
\text { importance }\end{array}$ \\
\hline 1 & $\begin{array}{l}\text { Your bank will develop and } \\
\text { diversify services that will } \\
\text { attract deposits. }\end{array}$ & 4.44 & 0.87 & 88.8 & high \\
\hline 2 & $\begin{array}{l}\text { Your bank develops e-services } \\
\text { to attract customers. }\end{array}$ & 4.28 & 0.74 & 85.6 & high \\
\hline 3 & $\begin{array}{l}\text { Your bank offers completely } \\
\text { banking services. }\end{array}$ & 4.16 & 0.94 & 83.2 & moderate \\
\hline 4 & $\begin{array}{l}\text { Your bank continuously } \\
\text { reviews the services provided } \\
\text { by international Islamic banks. }\end{array}$ & 4.16 & 0.94 & 83.2 & moderate \\
\hline 5 & $\begin{array}{l}\text { Your bank focuses on providing } \\
\text { banking services with the } \\
\text { utmost accuracy and speed. }\end{array}$ & 4.12 & 0.97 & 82.4 & moderate \\
\hline 6 & $\begin{array}{l}\text { Your bank focuses on providing } \\
\text { banking services at the lowest } \\
\text { cost to customers. }\end{array}$ & 3.72 & 1.06 & 74.4 & Low \\
\hline & All grouped items & 4.1 & 0.51 & 83 & moderate \\
\hline
\end{tabular}

In view of the table data, we note that the diversifying and developing services of Palestinian 


\section{Macrothink}

Asian Journal of Finance \& Accounting

ISSN 1946-052X

2017, Vol. 9, No. 1

Islamic banks has a moderate impact on attracting deposits. This is because the Islamic banks in Palestine are not focused on providing banking services with the utmost accuracy and speed, and are not focused on providing banking services at the lowest cost to customers, because that the semi-fixed cost in the all of banks operating in Palestine.

\subsection{Fourth hypothesis}

There is a statistical relationship between attracting deposits and the experience of customer service staff in Palestinian Islamic banks.

The table (7) shows that all grouped items have a mean of 4.2, is the larger of about 1.2 average defaults (3), which means that this hypothesis is accepted, and there is a statistical relationship between attracting deposits and the diversifying and developing the services of Palestinian Islamic banks.

Table (7) shows that the experience of customer service staff in Palestinian Islamic banks play a high role in attracting deposits. Paragraph (1) has a very high effect. The percentage of respondents' (93.6), while in paragraph (2) has a high effect. The percentages of responses (86.4), and the paragraphs ( 3,4 , and 5) have a moderate effect and percentages of responses $(82.4,81.6$, and 79.2$)$ respectively.

The overall degree of experience of customer service staff was a high. With the overall percentage of responses in this area (84.6).

Table 7. Arithmetical averages, standard deviations and percentages of the experience of customer service staff in Palestinian Islamic banks.

\begin{tabular}{|c|l|c|c|c|c|}
\hline No & \multicolumn{1}{|c|}{ Paragraph } & $\begin{array}{c}\text { arithmetic } \\
\text { means }\end{array}$ & $\begin{array}{c}\text { standard } \\
\text { deviations }\end{array}$ & \% & $\begin{array}{c}\text { relative } \\
\text { importance }\end{array}$ \\
\hline 1 & $\begin{array}{l}\text { Your bank is keen to training customer } \\
\text { service staff to attract deposits. }\end{array}$ & 4.68 & 0.48 & 93.6 & very high \\
\hline 2 & $\begin{array}{l}\text { Lack of knowledge of foreign-language } \\
\text { to customer service staff hinders the } \\
\text { process of attracting deposits. }\end{array}$ & 4.32 & 0.69 & 86.4 & high \\
\hline 3 & $\begin{array}{l}\text { There is obvious plan to training } \\
\text { customer service staff to attract } \\
\text { deposits. }\end{array}$ & 4.12 & 0.88 & 82.4 & moderate \\
\hline 4 & $\begin{array}{l}\text { The results of the training assessment } \\
\text { are used to improve staff performance to } \\
\text { attract deposits. }\end{array}$ & 4.08 & 0.91 & 81.6 & moderate \\
\hline 5 & $\begin{array}{l}\text { Training workshops held for customer a } \\
\text { service staff who is interested in } \\
\text { spreading Islamic banks in other } \\
\text { countries in the field of attracting } \\
\text { deposits. }\end{array}$ & 3.96 & 0.79 & 79.2 & moderate \\
\hline \begin{tabular}{l} 
All grouped items \\
\hline
\end{tabular}
\end{tabular}


The table's data reflect that Islamic banks compete by taking care of customers through the experience of the employees and training them to attract customers, and that the other languages are important to attract deposits.

This is consistent with Mohammed, (2010) study which recommended that the banks need to seek to attract funds outside the banking system, and it's necessary to increase the training and rehabilitation of employees in Islamic banks.

\section{Results}

There is a statistically significant relationship between the study variables (geographic location, advertising campaigns Promotions, diversification and development of services, employee experience) and attracting deposits in Islamic banks in Palestine.

1. The results of the factors analysis showed that the most important factors to attract deposits in the Palestinian Islamic banks are ranked as important:

- $\quad$ First: the advertising campaigns Promotions offered by the Palestinian Islamic banks.

- Second: the Geographical location of branches of the Islamic Bank.

- Third: the Experience of customer service staff in Palestinian Islamic banks.

- Forth: the diversity and the development of services offered by Islamic banks in Palestine.

2. The results also showed a shortage of Islamic finance specialty, which could increase the volume of deposits in Islamic banks for religious beliefs.

3. The results also revealed that there are restrictions by the supervisors of Islamic banks regarding the appointment of branch managers, namely the specialization, the number of years of experience, and some training courses.

\section{Recomendations}

1. The study recommends that the Islamic banks in Palestine continuously provide savings campaigns to increase deposits.

2. The study recommends that the Islamic banks must choose locations based on the recommendations of branch managers. And the involvement of marketing departments.

3. The management of Islamic banks in Palestine should direct their appointments to the managers and staff of customer service for Islamic finance specialty.

4. The Islamic banks in Palestine should increase investment in human resources in terms of training, qualification and work to provide them with the necessary skills to attract customers.

\section{References}

Almejyesh,S., \& Rajha, k. (2014). Behavioral Determinants and Their Impact on Customer Savings Deposits in Islamic Banks in Saudi Arabia. Journal of Islamic Banking and Finance, 
2(1).

Garit, Essam. (2010). the impact of Central Bank control in deposits and credit in Islamic banks applied in Syria International Islamic Bank. Damascus University Journal of Economics and legal, 27(3).

Kasri, R., \& Kassim, S. (2009). Empirical Determinants of Saving in the Islamic Banks: Evidence from Indonesia. JKAU: Islamic Econ., 22(2).

Matloob, Mustafa Nateq Saleh. (2012). Obstacles to the work of Islamic banks and access to treatment for their development. Journal of Islamic Research and studies, 29, 20712847: ISSN pages, 287-333.

Rosly, S., \& Zaini, M. (2008). Risk-return analysis of Islamic banks' investment deposits and shareholders' fund. Emerald Group Publishing Limited. Managerial Finance, 34(10), 695-707. https://doi.org/10.1108/03074350810891010

Alwadi, Hussein, \& Samhan, Hussein. (2009). Islamic banks the theoretical foundations and practical applications. First edition, Dar al-Massira for publishing and distribution, Amman. Jordan

Al-Zubaidi, Mahmoud. (2011). Department of banking deposit mobilization strategy and the extension of credit. Alwarraq Foundation for Publishing and Distribution, Amman.

Othman, Ahmed. (2010). statistical analysis of the role of commercial banks in mobilization of domestic savings to finance development in Syria. Faculty of Economics. Tishreen University.

Samhan, Hussein. (2013). Foundations of Islamic banking operations. first edition. Dar al-Massira for publishing. Distribution and printing. Amman. Jordan.

Sheikh, Othman, \& Fahad, Omar. (2009).Management of assets to liabilities of traditional banks and Islamic banks. Arabic Academy for banking and financial Sciences. Damascus. Syrian Arabic Republic. 